\title{
Can Microfinancing Improve Small and Medium Scale Enterprises in Lagos State, Nigeria
}

\author{
${ }^{1}$ Samuel Olumuyiwa Olusanya, ${ }^{2}$ Babatunde Jelili Sufian, ${ }^{3}$ Olajide-Arise Temi \\ ${ }^{I}$ Assistant LecturerNational Open University of Nigeria. Economics Unit \\ ${ }^{2}$ Lecturer SchoolofManagement SciencesNational Open University OfNigeria, Victoria Island, Lagos, Assistant, \\ ${ }^{3}$ Lecturer National Open University Of Nigeria.School of Management Science entrepreneurial and Business \\ Management Unit
}

\begin{abstract}
Microfinance is the array of financial services, including loans, savings and insurance, available to poor entrepreneurs and small business owners who have no collateral and would not otherwise qualify for a standard bank loan. Most often, microloans are given to those living in still-developing countries who are working in a variety of different trades, including carpentry, fishing and transportation. However, the paper makes use primary data and questionnaire were distributed to fifty (50) staff of AB microfinance bank, Ikeja branch, Lagos state and fifty (50) selected small and medium scale enterprises in Ikeja metropolis, Lagos State, Nigeria and Spearman's rank correlation coefficient was adopted as the estimation techniques. The paper set to examinethe impact of micro finance bank on small and medium enterprises in Nigeria and to also examine the impact of micro finance policy on employment opportunities in Nigeria. More so, the result shows that Microfinance bank has a significant effect on the growth of small enterprises in Nigeria and Microfinance policy has a significant effect on employment opportunities in Nigeria. Therefore, the paper concludes that the government should focus more on promoting small and medium scale enterprises (SMEs) in Nigeria by giving more microfinance banks opportunity to operate freely and give loan to the SMEs in Nigeria. Finally, the paper recommends that small and medium scale enterprises (SMEs) is seen as the way forward for Nigerian economy rather than relying on oil that has not transformed the economy, so the Nigerian government should embrace SMEs and give more support to the microfinance bank in other to give loan to the SMEs in Lagos State Nigeria.

Keywords: Microfinance, Financial Services, Loans, AB microfinance bank, Small and Medium Scale enterprises, Spearman's rank correlation coefficient, Finance policy, Employment Opportunity.
\end{abstract}

\section{Introduction}

Effectively functioning financial markets have fundamental roles to play in fostering development. At the level of individual livelihoods, financial markets can perform very crucial functions. They can be a principal means for the poor to get financial assets; through facilitating saving, they can be of importance in reducing the vulnerability associated with uneven and unpredictable year to year changes in circumstances, and they can help convert illiquid assets into liquid ones in the event of emergencies. Nevertheless, sustainable economic growth cannot be achieved without putting up viable programmes to encourage the SME's, which are the engine of growth for all economies all over the world.(Olaweju, 2013).

However, Ajani (2014) said that the latent capacity of the poor for entrepreneurship would be significantly enhanced through the provision of micro finance services to enable them engage in economic activities and be more self-reliant, in turn improve their abilities to create wealth.In spite of the above, a few number of highly effective micro finance programs have demonstrated that low-income clients especially women can manage meager resources productively provided the interest rate is relatively low.However, Dale (2014) asserts that over the past decade, a few' pioneer micro finance institutions have demonstrated not only the bank ability of the poor but also the potential for sustainability of financial institution that serve the poor. Full financial sustainability is reached when administrative; loan loss, inflation and financial costs are covered entirely by revenues. Savings services are needed urgently by the large number of poor people around the world to protect their income and serve as an alternative to acquisition of debt, micro finance institutions are therefore increasingly under pressure to mobilize savings to assist the poor. Moreover, savings deposit also offers micro finance institutions a valuable source of getting substantial local funds. Before the emergence of formal micro finance institutions, the informal associations that operate traditional micro finance in various forms are found in all the rural and urban communities in Nigeria (Otu,et al, 2013). The practice of micro finance in Nigeria is dated back to several centuries ago. The traditional micro finance institutions work together for mutual benefits of their members; these groups provide access to credit for the rural and urban, low-income earners. They are mainly the informal self-help groups or rotating saving and credit association types. Other providers of micro finance services include savings collectors and co-operative societies. The informal model is built around group 
concept. The model works in a situation where groups whose commitment to savings and credit are weak and look up to donor-sponsored credit, and informal model include, TheGrameen Bank experience of Bangladesh founded by Mohammed Yunus which started with the group concept-informal lending to the poor. The program has since been linked to formal micro credit model. The model had been quite successful as a bank for the poor and as a social movement based on principles of awareness and training, which has facilitated active participation of the poor. As at 1999, the Grameen Bank had provided its services to about 1.5 million poor, unified about 60,000 small village banks on the linkage process and about $\$ 480$ million to its clients for smallscale trade. Moreover, non-Governmental Organization tends to adopt the Grameen principles, and is usually gender specific and sectorally motivated. There are women groups, farmers union; trade union etc. in different parts of Nigeria, a revolving loan scheme is practiced where members make fixed contributions of money at regular intervals to assist in financing their small-scale businesses. At each interval, one member collects the entire contributions of money from all. Among, the Yorubas it is called "Esusu", Hausas call it "Adashi" while Igbos call it "Itutu". It could also serve as a savings mechanism to the members. The demand for micro finance services is high and increasing in Nigeria. the continuous lay-off of labour from both the public and private sectors since the introduction of structural adjustment programme in 1986 and the growing number of graduates from schools is pushing a large proportion of the population into informal sector activities. (Yinusa, 2014).Many micro enterprises are, therefore, springing up but without bank financial support. Also, the domestic market is large, with over 140 million people in need of various goods and services, including financial services. The growth in micro finance activities reflects the expansion of informal sector activities and the exclusion of a large proportion of economically active population from the various financial services of the formal sector. (Keagan, 2013).The micro finance policy seeks to make financial services available on a sustainable basis to the economically active poor, low-income earners and the micro, small and medium enterprises through privately owned banks (microfinance banks). This is to create a vibrant micro finance sub-sector that provides the necessary stimulus for national growth and economic development.Notwithstanding the predominant positive view of microfinance in the development of the economy, it has been studied by several researchers that micro finance services does not reach the poorest of the poor (Scully, 2004).However, another challenge of micro finance banks is that most of its funding goes to the commercial sector to the detriment of the more vital economic activities especially agricultural and manufacturing sector which provide the foundation for sustainable growth and development of the economy. Currently, only about 14.1 and 3.5 percent of the total MFI funding went to these sectors respectively, while the bulk 78.4 percent funded only commerce (Sowunmi, 2009).In addition, instability of interest rates is also faced by micro finance bank in Nigeria. Interest rates in the micro finance bank are much higher than the prevailing rates in commercial banks and money lenders at informal sector charge interest rates of $100 \%$. However, the objective of the study is to examine the impact of micro finance bank on small and medium enterprises in Nigeria and to also examine the impact of micro finance policy on employment opportunities in Nigeria.

\subsection{Literature Review}

\section{Literature Rewiew And Theoretical Frame Work}

The growing awareness of the potential of microfinance in poverty reduction, economic growth and development coupled with the emergence of several highly successful and fast growth MFIs has effectively put the issue of microfinance on the political agenda of most developing countries.

After the 1970s, the number of microfinance institutions around the world proliferated at a fast pace. In view of the dismal performance of the conventional finance sector, policy makers, practitioner and international organizational finance sector, policy makers, practitioner and international organization advocated micro financing as the tool for poverty reduction. Today there are more than 700 micro lending organization providing loans to more than 25 million poor individuals across the world, the vast majority of who are women. The United Nation Capital Development Fund declared 2005 as the year of micro credit. The success of Grameen Bank model in Bangladesh which offered loans to poor people through group collateral was emulated in many countries worldwide. (Feranmi, 2014). MFI round the world have been able to help household meet basic needs and protect against risk by providing financial services to the poor and low income people whose economic standing exclude them from formal financial systems. Microfinance is a poverty alleviation tool. It's provision of financial services to the poor helps to increase household income and economic security, build assets and reduce vulnerability, creates demand for other goods and services (especially nutrition, education and health care) and stimulates local economies.

\subsubsection{What Is Microfinance?}

Microfinance, according to Otero (1999), is the "provision of financial services to low income, poor and very poor self employed people". These financial services according to him generally include savings and credit but can also include other financial services such as insurance and payment services. 
Schreiner and Colombet (2001), define microfinance as the attempt to improve access to small deposits and small loans for poor households neglected by banks.According to Convoy (2003), microfinance is the provision of financial services to poor and low income households without access to formal financial institutions. Mix (2005), defined microfinance organization as one that offers financial services to the poor.

\subsection{Theoretical Framework}

\subsubsection{Providers And Models Of Microfinance Intentions}

The Grameen Bank (2000) identified three different microfinance models. These are:

\section{Rotating Savings And Credit Allowance}

According to Grameen (2000), Rotating Savings and Credit Allowance are formed when a group of people come together to make regular cyclical contribution to a common fund, which is then given as a lump sum to one member of the group in each style.

Harper (2002) declares that this model is a very common form of savings and credit. He states that the members of the group are usually neighbours and friend, and the groups providean opportunity for social interaction and are very popular with women. They are also called merry-go rounds or Self Help Groups (Fisher and Sriram, 2002).

\section{The Grameen Solidarity Group Model}

Berenbach and Guzman (1994) said this model is based on group peer pressure where loans are made to individuals in group of four to seven. Group members collectively guarantee loan repayment, and access to subsequent loans is dependent on successful repayment by all group members. Payments are usually made weekly (Ledgerwood, 1999).

According to Berenbach (1994), solidarity group have proved effective in deterring defaults as evidenced by loan repayment rate attained by organization such as the Grameen Bank, who was the type of microfinance model. They also highlight the fact that this model has contributed to broader social benefits because of the mutual trust arrangement at the heart of the group guarantee system. The group itself becomes the building block to a broader social network. (Grameen, 1994).

\section{Village Banking Model}

Holt (1994) stated that village banks are community managed credit and saving association established by NGOs to provide access to financial services, build community self help groups and help members accumulate savings.

Grameen Bank (2000) also revealed that village bank has been in existence since the mid 1980s. he said they usually have $25-30$ members who are low-income individuals seeking to improve their lives through self employment activities. These members run the bank, elect their own officers, establish their own by-laws, distribute loan to individuals and collect payment and services. The loans are backed up by moral collateral; the promise that the group stands behind each loan. (Global Development Research Centre, 2005).

Ledgerwood (1999) maintained that the sponsoring MFIs lend loan to the village bank, who in turn lend to members. Members saving are tied to loan amount and are used to finance new loans or collective income generating activities so they stay within the village bank. No interest is paid on savings but members receive a share of profit from the village bank's re-lending activities. Many village banks target women predominantly, as According To Holt (1994).

\subsubsection{Overview Of Small And Medium Scale Enterprises}

According to Oluseye (2014), the role of the Small and Medium Enterprises as a catalyst for economic growth and development has been well recognized in most countries of the world. For example, in many newly industrialized nations, more than 98 per cent of all industrial enterprises belong to the SMEs sector and account for the bulk of the labour force. This is why countries, particularly the developed ones, put policies in place to ensure continuous growth of the sector.But the growth journey for small and medium enterprises in Nigeria has been a rather slow one, even though policy makers are not oblivious of the positive impact of the vibrancy of small businesses on the country's growth and poverty reduction objectives.

There have been many attempts by government and policy makers to harness the benefits of an active SME sector to jump-start the economy but these efforts, according to experts, have not yielded visible results. Worried by the stagnant growth that has characterized the sector for long and its inability to perform its developmental role in the country's economy due, largely, to financial squeezes, the Bankers' Committee at the initiative of the Central Bank of Nigeria introduced the Small and Medium Industries Equity Investment Scheme (SMIEIS) in 2001.

The scheme was aimed at providing financial and managerial expertise to small and medium businesses in the country to set aside 10 per cent of their pre-tax profit for equity investment in the SME's.(Raji, 2013). 
According to the Central Bank of Nigeria, under the scheme, the funds set aside by banks increased from N13,1bn in 2002 to N41.4bn in 2005, but actual investment grew much lower, from N2.2bn in 2002 to N12.1bn in 2005 , representing only 29.1 per cent of the funds set aside.with the improved status of the Nigerian banks after the consolidation, hopes were again raised that the real sector would be delivered from the lingering financial crises that had rendered it uncompetitive. Laudable as these moves were, they failed to do the needed magic of turning around the fortunes of the real sector, particularly the small businesses.

The CBN in its quest for a better operating environment for small businesses, launched the micro finance policy, regulatory and supervisory framework inaugurated on December 15, 2005 to restructure the community banks into vibrant micro finance banks primarily to help finances SMEs effectively. Private investors with the desire and ability to operate micro finance institutions were statutorily empowered to do so. A two-year period, ending December 31, 2007 was, therefore, given to existing Community Banks to re-capitalize and convert to micro finance Banks.

The micro finance banks is expected to reach out the expand access to finance to the unbanked and vulnerable groups, and empowers the active poor to alleviate poverty and create wealth. this will stimulate employment generation, economic growth and development.

\section{Methodology}

The paper makes use of primary dataand questionnaire were distributed to $50 \mathrm{AB}$ microfinance bank plc, Ikeja, Lagos State, Nigeria and 50 selected small and medium scale enterprises in Ikeja metropolis, Lagos State, Nigeria while Spearman's rank correlation coefficient was adopted as the estimation technique.However, the formula for Spearman's rank-order correlation is as follows:

$\mathrm{R}=1-6 \sum \mathrm{d}^{2}$

$\mathrm{n}\left(\mathrm{n}^{2}-1\right)$

Where $\quad d=$ the difference between the ranks of each pair.

$\mathrm{n}=$ number of paired observations

\subsection{Discussion Of Questionnaire}

From the questionnaire, the result above reveals that 3 out of 100 respondents strongly agree that it is good and preferable to borrow money from lender and it gives 3\% of the total respondents. 8 respondents disagree with the notion, 43 strongly disagree and 46 respondents disagree with the notion and all this constitutes $8 \%, 43 \%$ and $46 \%$ of the while respondents. We can then conclude that it is not preferable and good to borrow money from the lender. However, 80 out of 100 respondents said it is preferable and good to borrow from microfinance and this represent $80 \%$ while 20 out of 100 respondents agreed with the notion and this gives $20 \%$ of the total respondents. However we can conclude that it is more preferable to borrow from microfinance institution.

It was also evident from the questionnaire that 21 out of 100 respondents strongly agree that microfinance institution are for poor and low income earners and entrepreneurs and this represent $21 \%$ of the total respondents while 77 out 100 respondents also agree with the notion. However nobody strongly disagree while 2 disagree with notion. Therefore we can conclude that microfinance institutions are for poor and low income earners and entrepreneurs. 88 out of 100 respondents said microfinance institutions have helped in enhancing the growth of small and medium enterprises while 12 out of 100 respondents agreed with the notion. Therefore we can then conclude that microfinance institutions have helped in enhancing the growth of small and medium enterprises.

From the result, it shows that 3 out of 100 respondents agree that microfinance has no impact on small and medium enterprises and this constitutes $3 \%$ of the whole respondents. However, 85 out 100 respondents strongly disagree with the notion and this gives $85 \%$ of the total respondents while 12 disagree with the notion and this gives $12 \%$ of the total respondents. We can then conclude that microfinance has an impact on the small and medium enterprises and this constitutes $3 \%$ of the whole respondents. However, 85 out 100 respondents strongly disagree with the notion and this gives $85 \%$ of the total respondents while 12 disagree with the notion and this gives $12 \%$ of the total respondents. We can then conclude that microfinance has an impact on the small and medium enterprises.

More so, 22 respondents disagreed with the notion and this gives $22 \%$ of the total respondents while 78 out of 100 respondents disagreed that microfinance institutions are for high income earners and entrepreneurs. Therefore we can conclude that microfinance institutions are not meant for high income earners and entrepreneurs while 93 out of 100 respondents strongly agreed with the notion and this constitutes $93 \%$ of the while respondents while 7 out of 100 respondents agreed with the notion and this represent $7 \%$ of the total respondents, where nobody strongly disagree nor disagree. Therefore we can then conclude that economic growth cannot be achieved if entrepreneurs do not have access to production especially credit. 
The result also shows that 98 out of 100 respondents strongly agreed that microfinance had helped in creating employment thereby reducing poverty and this gives $98 \%$ while 2 out 100 respondents agreed with the notion and this constitute $2 \%$ of the while respondents. We can then conclude that microfinance had helped in creating employment thereby reducing poverty while 6 out of 100 respondents strongly disagree that soliciting for small and medium fund from microfinance institution is not ideal and this gives $6 \%$ while 94 out of 100 respondents disagreed with the notion. Therefore, we can then conclude that soliciting for small and medium fund from microfinance institution is ideal.

Furthermore, 91 out of 100 respondents strongly disagreed that soliciting for small fund from microfinance institution is better and this constitutes $91 \%$ of the whole respondents while 9 out of 100 respondents disagreed with the notion and this represent $9 \%$ of the total respondents. However we can then conclude that soliciting for small fund from microfinance institution is not better while 96 out of 100 respondents strongly agreed that more people should invest in microfinance sector to ensure growth in SMES and this constitutes $96 \%$ of the total respondents while only 4 respondents agreed with the notion and this gives $4 \%$ of the total respondents. We can then conclude that more people should invest in microfinance sector to ensure growth of SMES.

8 respondents strongly agreed that microfinance provides loan and credit to small and medium scale entrepreneurs at a lower interest rate and this represent $8 \%$ of the total respondents while 92 respondents agreed with the notion and this represent $92 \%$ of the whole respondents. We can then concludes that microfinance provides loan and credit to small and medium scale entrepreneurs at a lower interest rate while 88 respondents strongly agreed on the question and this gives $88 \%$ of the whole respondents while 12 respondents also agreed with the question and this represent $12 \%$ of the total respondents. Therefore we can then conclude that there is need to empower the small and medium scale entrepreneurs with fund (credit) to achieve economic development.

Moreover, only 5 respondents agree that microfinance provide loan and credit at a higher interest rate, and this gives $5 \%$ of the whole respondents, while 20 respondents strongly disagreed with the notion and this constitution $20 \%$ of the total respondents, 75 respondents disagreed with the notion and this represent $75 \%$ of the whole respondents. However, we can then concludes that microfinance provide loan credit at a higher interest rate while 72 respondents strongly agreed with the question, 21 respondents agreed while 7 respondents strongly disagreed with the question and all these constitutes $72 \%, 21 \%$ and $7 \%$ of the whole respondents. Therefore, we can then include that microfinance programme have increased the self sufficiency of entrepreneurs.

It was also evident from the result that 69, 25, and 6 respondents agreed, strongly disagreed and disagreed with the question and all these represent $69 \%, 25 \%$ and $6 \%$ of the total respondents. However, we then conclude that microfinance is necessary for the development of an economy while 23 above reveals that 97 respondents strongly disagreed with the question and it indicates $97 \%$ of the while respondents and 3 respondents disagreed with the question and this gives $3 \%$ of the total respondents. Moreover, we can conclude that economic growth cannot be achieved without the provision of credit facilities to entrepreneurs.

16 respondents $(16 \%)$ strongly agree with the question while 84 (84) respondents agreed with the question. Therefore we can then conclude that the number of small and medium scale entrepreneur have increased due to microfinance programme and it was evident that 6 out of 100 respondents strongly agreed with the question and this gives $6 \%$ of the total respondents while 6 out of 100 respondents agreed with the question and it indicates $94 \%$ of the while respondents. Therefore, we can conclude that microfinance helps in the provision of employment hence reduces of unemployment in an economy.

84 out of 100 respondents /strongly agreed microfinance has a positive effect on the development of an economy and this represent $84 \%$ of the total respondents while only 16 respondent agreed with the notion and it gives $16 \%$ of the whole respondents. However, we can then conclude that microfinance has a positive effect on the development of an economy while 98 respondents strongly agreed with the question and this gives $98 \%$ of the while respondents while 2 respondents agreed with the notion and it gives $2 \%$ of the whole respondents. Therefore, we can conclude that microfinance helps to ensure that the standard of living of masses in an economy is increased.

9 respondents strongly agreed with the question and it gives 9\% of the total respondents and 91 respondents agreed with the question and this represents $91 \%$ of the total respondents. Therefore, we can then conclude that microfinance help to create access to productive capital for small business owners while 4 respondents, 10 respondents, 22 respondents strongly agreed, agreed and strongly disagreed with the question and all these gives $4 \%, 10 \%$ and $22 \%$ of the total respondents while 64 respondents disagreed with the question and this represent $64 \%$ of the whole respondents. We can then conclude that with the access to productive capital fro micro-entrepreneurs, entrepreneurship which is the backbone of a developing economy are not encouraged. 
93 respondents strongly agreed with the question and this gives $93 \%$ of the while respondents while 7 respondents agreed with the question and this gives $7 \%$ of the total respondents. We can then conclude that micro-finance offer loans to small business owners and micro entrepreneurs at a low interest rate and 8 respondents strongly agreed that microfinance holds big promises to alleviate poverty in Nigeria and it represents $8 \%$ of the table respondents while 92 respondents agreed with the question which gives $92 \%$ of the whole respondents and we can then concludes that microfinance holds big promises to alleviate poverty in Nigeria.

\subsection{Analysis Of The Spearman's Rank Correlation Coefficient}

\subsubsection{Analysis Of Research Hypothesis 1}

Null hypothesis $\left(\mathrm{H}_{\mathrm{o}}\right)$ :- Microfinance bank has no significant effect on the growth of small and medium enterprises in Nigeria.

Alternative Hypothesis $\left(\mathrm{H}_{1}\right)$ : Microfinance bank has a significant effect in the growth of small enterprises in Nigeria.

Decision Rule: Accept Hi when the value of spearman's rank correlation coefficient is positively significant level less than the value of 0.05 ( $5 \%$ level of significance) otherwise accept $\mathrm{H}_{\mathrm{o}}$ the null value.

If tabulated (0.05) is greater than $\mathrm{H}$ calculated, we then accept the null hypothesis $\left(\mathrm{H}_{\mathrm{o}}\right)$ and reject the alternative hypothesis. However, if $\mathrm{H}$ calculated is greater than $\mathrm{H}$ tabulated $(0.05)$, we then accept the alternative hypothesis $\left(\mathrm{H}_{1}\right)$ and reject the null hypothesis $\left(\mathrm{H}_{\mathrm{o}}\right)$.

\section{Result Of Spearman's Rank Correlation Coefficient} For Research Hypothesis I

\begin{tabular}{|c|c|c|c|c|}
\hline & & & Q1 & Q9 \\
\hline Spearman's rho & & $\begin{array}{l}\text { Correlation Coefficient } \\
\text { Sig. (2-tailed) } \\
\text { N } \\
\text { Correlation Coefficient }\end{array}$ & $\begin{array}{l}1.000 \\
100 \\
.766 * *\end{array}$ & $\begin{array}{c}.766 * * \\
.000 \\
100 \\
1.000\end{array}$ \\
\hline & & $\begin{array}{l}\text { Sig. (2 tailed) } \\
\text { N }\end{array}$ & $\begin{array}{l}.000 \\
100\end{array}$ & 100 \\
\hline
\end{tabular}

Source: SPSS PACKAGE

Spearman's correlation coefficient $r=0.766$ here we have a strong and positive significant relationship is established as reflected in the spearman's rank correlation coefficient result $r=0.766$.

However, the tabulated value of 0.05 ( $5 \%$ level of significant) is less than the spearman's rank correlation coefficient $r=0.766$, so we can deduce here that $\mathrm{H}$ calculated is greater than $\mathrm{H}$ tabulated, we then accept the alternative hypothesis and reject the null hypothesis, then conclude that microfinance bank has a significant effect on the growth of small and medium enterprises in Nigeria.

\subsubsection{Analysis Of Research Hypothesis Ii}

Null hypothesis $\left(\mathrm{H}_{\mathrm{o}}\right)$ : Micro finance policy has no significant effect on employment opportunities in Nigeria. Alternative Hypothesis $\left(\mathrm{H}_{1}\right)$ : Microfinance policy has a significant effect on employment opportunities in Nigeria.

Decision Rule: Accept Hi when the value of spearman's rank correlation coefficient is positively significant level less than the value of 0.05 ( $5 \%$ level of significance) otherwise accept Ho the null value.

If tabulated (0.05) is greater than $\mathrm{H}$ calculated, we then accept the null hypothesis $\left(\mathrm{H}_{\mathrm{o}}\right)$ and reject the alternative hypothesis. However, if $\mathrm{H}$ calculated is greater than $\mathrm{H}$ tabulated $(0.05)$, we then accept the alternative hypothesis $\left(\mathrm{H}_{1}\right)$ and reject the null hypothesis $(\mathrm{H})$.

Result Of Spearman's Rank Correlation Coefficient For Research Hypothesis Ii

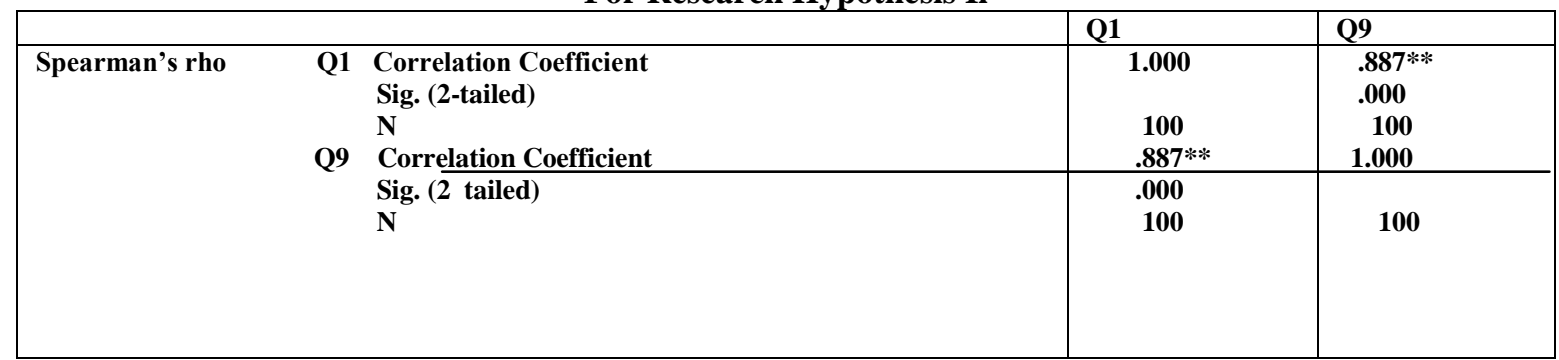

\section{Source: SPSS PACKAGE}

Spearman's Rank correlation coefficient $r=0.887$ Here we have a positive and strong significant correlation coefficient relationship is established. Base on the result above, the $\mathrm{H}$ calculated $(0.887)$ is greater than $\mathrm{H}$ 
tabulated (0.05), then the decision rule is that we accept the alternative hypothesis and reject null hypothesis then concludes that microfinance policy has a significant effect on employment opportunities in Nigeria.

\section{Recommendations}

The following are the recommendation of the research study

1. There should be diversification of the economy, because our country's economy has over the decades relied heavily on its oil production, we must find ways to diversity our economy and avoid the over reliance on oil. A small and medium enterprise is seen as an essential key if we want our country to achieve its ambition of being an industrialized nation.

2. Government should give more microfinance bank licenses to operate so that they can give loans to the SMEs in Nigeria.

3. Unfriendly business climate should be avoided because Nigeria requires great determination as practicing and potential business owners, microfinance and small and medium enterprises are faced with countless challenges. Nigerian's business climate should be made welcoming to those in the micro, small and medium enterprises because the role played by these small and medium enterprises should not be underestimated since majority of the thriving businesses fall in this category and for us to achieve our goals, adequate attention and support must be directed towards these institutions.

4. Avoidance of failure to adapt to the changing business environment because majority of those who venture into both microfinance and small and medium enterprises are in the business of the money they want to make. In most cases, such business lack relevant and adequate information about the business they engage. So all these should be avoided by having better thinking mind towards been in business rather than their selfish interest.

5. Policy on Microfinance lending to small and medium enterprises should be encouraged because some microfinance bank do not give loan to the SMEs, so there should be a policy by central Bank of Nigeria mandating the microfinance bank to give loan to the small and medium enterprises in Nigeria.

\section{Conclusion}

Micro financing is not a new concept. Small microcredit operations have existed since the mid 1700s. Although most modern microfinance institutions operate in developing countries, the rate of payment default for loans is surprisingly low - more than $90 \%$ of loans are repaid.

Like conventional banking operations, microfinance institutions must charge their lenders interests on loans. While these interest rates are generally lower than those offered by normal banks, some opponents of this concept condemn microfinance operations for making profits off of the poor. The World Bank estimates that there are more than 500 million people who have directly or indirectly benefited from microfinance-related operations.

In conclusion, the government should focus more on promoting small and medium scale medium enterprises in Nigeria by giving more microfinance banks opportunity to operate freely and give loan to the small and medium enterprises in Nigeria.

\section{References}

[1]. Ajani O. O. (2001). A paper presented on "Micro finance as a strategy for poverty reduction" macmilliam press publication page 4-10 (2001).

[2]. Berenbach, D., Guzman, B.Gierameen, F, Holt, T. (1994). Group peer pressure contribution, a textbook, $6^{\text {th }}$ edition, pages $66-$ 117 Grawhill press limited, 1994.

[3]. Dale, J.J. (2014), A paper presented on "micro finance institutions in Nigeria: policy, practice and potential", university of Lagos publication 2004 page $4-12$ (2004).

[4]. Fisher and Sriram (2002). Savings and credit toward development in Sweden, a university of lund publication, $4^{\text {th }}$ edition, pages 107 - 132, lund university press limited Sweden.

[5]. Feranmi, R.E. (2014). Loans and economic development a textbook, $3^{\text {rd }}$ edition pages 113 - 161, freshwood press limited, France.

[6]. Global Development Research center (2005). Loan with collateral, atextbook, $3^{\text {rd }}$ edition pages $66-103$ GDRC press limited, Nigeria.

[7]. Grameen Bank, (2000). Microfinance and its impact on small and medium enterprises in Bangladesh, a Journal, Vol 2, pages 33 - 49 Albakab Publication company limited.

[8]. Grameen Bank, (1994). Microfinance and its contribution on Bangladesh economy, $2^{\text {nd }}$ edition, pg 44-56, Albakab Publication limited.

[9]. Harper, A. D. (2002). Savings and credit towards development in Sweden, auniversity of lund publication, $4^{\text {th }}$ edition pages 107 132, lund university press limited Sweden.

[10]. Holt, A. W (1994). "Entrepreneurship Development ProgrammeA social science Journal, page 5 - 10, tophill press publication 1997.

[11]. Keagan, B. S. (2013). Problems and Prospects of Small and Medium Scale Enterprises in Nigeria, $1^{\text {st }}$ edition, pg 55-67, Paul \& Paul Publication limited.

[12]. Ledgerwood, O. (1999). Loan disbursement in Belgiurnma textbook, $2^{\text {nd }}$ edition, pages $142-171$, woodhill press limited 1999 
[13]. Otero A. O. (1999). Provision of financial services A microfinance issue, university of Ibadan publication, sixth edition, page 66 -110 , university press, 1999.

[14]. Olaweju, M. M. (2013). Introduction to Econometrics, a broader perspectives, a textbook Pg 66-67, Macmillan Publication limited, Lagos, Nigeria.

[15]. Oluseye, Y. O. (2014).Microfinance in broader perspectives, a textbook, $2^{\text {nd }}$ edition, pages 88 - 142, Grawhill press limited, Belgium.

[16]. Otu, G. M. \&Otemmy, R.O \&Ellanner, D.D. (2013). Microfinance and its activities, Jurblin publication page 50 -88, university of New York press 2005.

[17]. Raji, F. A (2013). Microfinance development in Africa, a broadperspectives. Michill college of social science journal third edition, college press, South Africa, 2001.

[18]. Schreiner, T. and Colombet, G. (2001).Microfinance bank, an attempt to improveaccess to small loans for poor. Macgraw journal, $10^{\text {th }}$ edition, macgraw press, 2001

[19]. SOowunmi, I. L. (2009). Development and small and medium enterprises in Nigeria, atextbook on small scale management, pages 122 - 136, macmillian press limited Nigeria.

[20]. Scully, B. F (2004). Beyond Micro credit, putting development bank, India, SW publication page 401-409, university publication press India, 2004

[21]. Yinusa, E.W. (2000). Micro finance tools as a way forward for small scale industry, in Africa, a journal of African developing economy, vol 4, pages 222 - 316, African consortium press limited, nairobi, Kenya. 